\title{
30. RELATIONSHIP BETWEEN THE BENTHIC FORAMINIFERS AND THE OSTRACODES IN THE PLIOCENE-PLEISTOCENE TYRRHENIAN DEEP-SEA RECORD (ODP LEG 107, SITE 654) ${ }^{1}$
}

\author{
Maria Luisa Colalongo, ${ }^{2}$ Giancarlo Pasini, ${ }^{3}$ Angelo Poluzzi, ${ }^{2}$ and Rodolfo Sprovieri ${ }^{4}$
}

\begin{abstract}
Deep-water benthic ostracodes from the Pliocene-Pleistocene interval of ODP Leg 107, Hole 654A (Tyrrhenian Sea) were studied. From a total of 106 samples, 40 species considered autochthonous were identified. Detailed investigations have established the biostratigraphic distribution of the most frequent ostracode taxa. The extinction levels of Agrenocythere pliocenica (a psychrospheric ostracode) in Hole 654A and in some Italian land sections lead to the conclusion that the removal of psychrospheric conditions took place in the Mediterranean Sea during or after the time interval corresponding to the Small Gephyrocapsa Zone (upper part of early Pleistocene), and not at the beginning of the Quaternary, as previously stated.

Based on a reduced matrix of quantitative data of 63 samples and 20 variables of ostracodes, four varimax assemblages were extracted by a Q-mode factor analysis. Six factors and eight varimax assemblages were recognized from the Q-mode factor analysis of the quantitative data of 162 samples and 47 variables of the benthic foraminifers.

The stratigraphic distributions of the varimax assemblages of the two faunistic groups were plotted against the calcareous plankton biostratigraphic scheme and compared in order to trace the relationship between the benthic foraminifers and ostracodes varimax assemblages. General results show that the two populations, belonging to quite different taxa, display almost coeval changes along the Pliocene-Pleistocene sequence of Hole 654A, essentially induced by paleoenvironmental modifications. Mainly on the base of the benthic foraminifer assemblages (which are quantitatively better represented than the ostracode assemblages), it is possible to identify such modifications as variations in sedimentation depth and in bottom oxygen content.
\end{abstract}

\section{INTRODUCTION}

The late Pleistocene and Holocene benthic ostracode faunas of the Mediterranean Sea have been the subject of many papers, mostly dealing with ostracodes of the continental shelf. On the contrary, data concerning the Pliocene-Pleistocene Mediterranean deep-water ostracodes are rather scarce (Benson and Sylvester-Bradley, 1971; Benson, 1972a, 1973, 1975; Bonaduce et al., 1983 , with references). In the present paper the ostracodes from the Pliocene-Pleistocene sediments of ODP Leg 107, Hole 654A, drilled in the Tyrrhenian Sea at a depth of $2208 \mathrm{~m}$ below sea level (Fig. 1), are examined.

The purposes of this paper are (1) to present the stratigraphic ranges of the ostracodes of Hole $654 \mathrm{~A}$ with reference to the calcareous plankton biostratigraphy of this hole as reported in Glaçon, Rio, and Sprovieri (this volume, Fig. 3); (2) to detect if the faunistic changes recognized in the ostracode populations occurred at the same stratigraphic levels in which faunistic changes were observed in the benthic foraminifer populations (Hasegawa, Sprovieri, and Poluzzi, this volume); (3) to detect if the same paleoenvironmental factors may account for the modifications of both faunistic groups.

As the number of ostracodes species recovered from each sample is small (Table 2), little could be inferred about the general evolution of the Mediterranean ostracode assemblages during the Pliocene-Pleistocene time interval.

\section{MATERIALS AND METHODS}

The data discussed in this survey are based on the analysis of coresamples from ODP Leg 107, Hole 654A (Fig. 1). The qualitative and

${ }^{1}$ Kastens, K. A., Mascle, J., et al., 1990. Proc. ODP, Sci. Results, 107: College Station, TX (Ocean Drilling Program).

2 Dipartimento di Scienze Geologiche dell'Universita' di Bologna, Italy.

3 Istituto di Geologia Marina del CNR, Bologna, Italy.

4 Dipartimento di Geologia e Geodesia dell'Universita' di Palermo, Italy. quantitative analyses were performed on 106 core samples for the ostracode assemblages (Table 2) and on 168 core samples for the benthic foraminifer assemblages (Sprovieri and Hasegawa, this volume; Hasegawa, Sprovieri, and Poluzzi, this volume).

From each core sample about $10 \mathrm{~cm}^{3}$ of sediment were taken, washed through a $63-\mu \mathrm{m}$ sieve and dried at $40^{\circ} \mathrm{C}$. All the specimens, including the instars of ostracodes, were picked out from the $>125-\mu \mathrm{m}$ residue fraction, identified, and counted. The relative abundances of the various taxa in each sample were calculated and used in the factor analysis.

Computational operations in foraminifer assemblages were carried out taking into account only samples with more than 50 specimens $(\mathrm{Ha}-$ segawa, Sprovieri, and Poluzzi, this volume). The original data set was therefore reduced to an array of 162 observations (or samples) per 47 taxonomic units (or variables), which was submitted to a Q-mode factor analysis (sample by sample confrontation).

Due to generalized paucity of specimens, in benthic ostracode assemblages we retained only samples with more than 5 specimens. A reduced array of 63 samples per 20 variables was organized and submitted to a Q-mode factor analysis.

In benthic foraminifers, the use of factor analysis was operationally dictated by the purpose of obtaining independent and ecologically significant varimax assemblages and of deriving some information on the main environmental changes recorded in the Pliocene-Pleistocene sequence of Hole 654A.

In benthic ostracodes, the factorial information strongly reflects the restriction of the input elements (small number of specimens per sample). This would compromise the reliability of independent paleoecological information from this basic faunistic group. Clustering techniques might be used in order to obtain aggregate samples and enrichment in specimens, but this criterion may be adopted only in presence of closely sampled levels. If samples are rather sparse along the cores as in Hole $654 \mathrm{~A}$, clustering might give not reliable results. Therefore the Q-mode factor analysis on the ostracode populations has been adopted prevailingly as a "data reduction" and "data ordering" criterion. No direct statistical inference has been drawn from the results of this factorial scheme. However, despite the limitations concerning the ostracodes, we believe that some general indications can be drawn from their factorial model, especially if compared with the results obtained from benthic foraminifers.

The factorial models were produced by the CABFAC program, that optionally computes a cosine theta similarity matrix from a normalized 


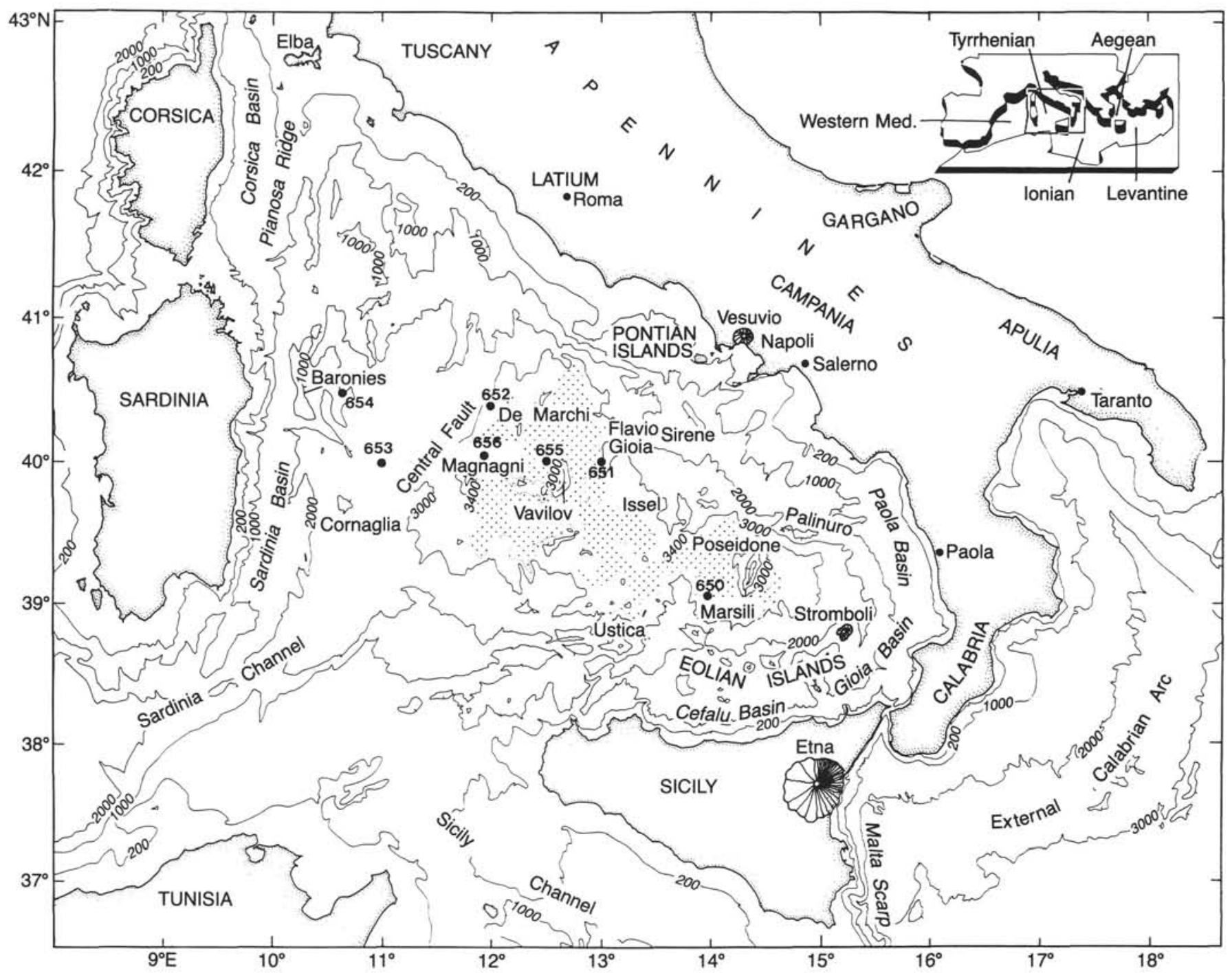

Figure 1. Location map of Site 654.

array of percentage data. In the following paragraphs, a short summary of the quantitative procedure is given. For more detailed explanations, the reader is referred to Imbrie and Kipp (1971).

\section{OSTRACODE BIOSTRATIGRAPHIC EVENTS}

A biostratigraphic scheme generally accepted for the Mediterranean Pliocene and Pleistocene ostracode faunas does not yet exist. On the other hand the ostracode faunas from Hole $654 \mathrm{~A}$ are too poor in species and specimens (Table 2) to allow constructing such a scheme. Moreover deep-water ostracode assemblages, as the ones found in Hole $654 \mathrm{~A}$, are not only less rich in specimens, but have been also less studied up to now than the shelf assemblages.

In this chapter only the species which-on the basis either of data gathered from literature or of unpublished data of two of the present authors (M.L.C. and G.P.)-seem to have significant stratigraphic ranges will be considered from a biostratigraphic point of view. All the statements in this chapter for which authors are not mentioned derive from unpublished data of M.L.C. and G.P.

The stratigraphic ranges of the ostracodes will be compared with the most important calcareous plankton biostratigraphic events (Figs. 2 and 3) recognized in Hole 654A by Glaçon, Rio, and Sprovieri (this volume).
In the following pages we will consider separately the ostracode events recorded in the Pliocene and in the Pleistocene sediments of Hole 654A. The abbreviations FO, LO, FAD, and LAD mean first occurrence, last occurrence, first appearance datum, and last appearance datum, respectively.

The Pliocene/Pleistocene boundary has been recognized by Glaçon, Rio, and Sprovieri (this volume) within sample 107654A-10R-1, 70-72 cm, 79.7 mbsf (meters below seafloor), as corresponding with the beginning of dominance of the left-coiling specimens of Neogloboquadrina pachyderma with respect to the right-coiling specimens: in fact in the Vrica section, this event is penecontemporaneous with the Pliocene/Pleistocene boundary stratotype (Aguirre and Pasini, 1985; Pasini and Colalongo, in press).

\section{Pliocene Ostracode Fauna}

In the Pliocene stratigraphic interval-stretching from 242.7 to 79.7 mbsf (Glaçon, Rio, and Sprovieri, this volume)-the ostracode assemblages are in general poor in specimens and species, among which the most frequent are Krithe aequabilis Ciampo (Pl. 1, Figs. 5-6), K. sinuosa Ciampo, Agrenocythere pliocenica (Seguenza), and Henryhowella asperrima (Reuss).

Zone MPI1 (Sphaeroidinellopsis Zone) and the lowermost part of Zone MP12 (Globorotalia margaritae Zone) are particu- 


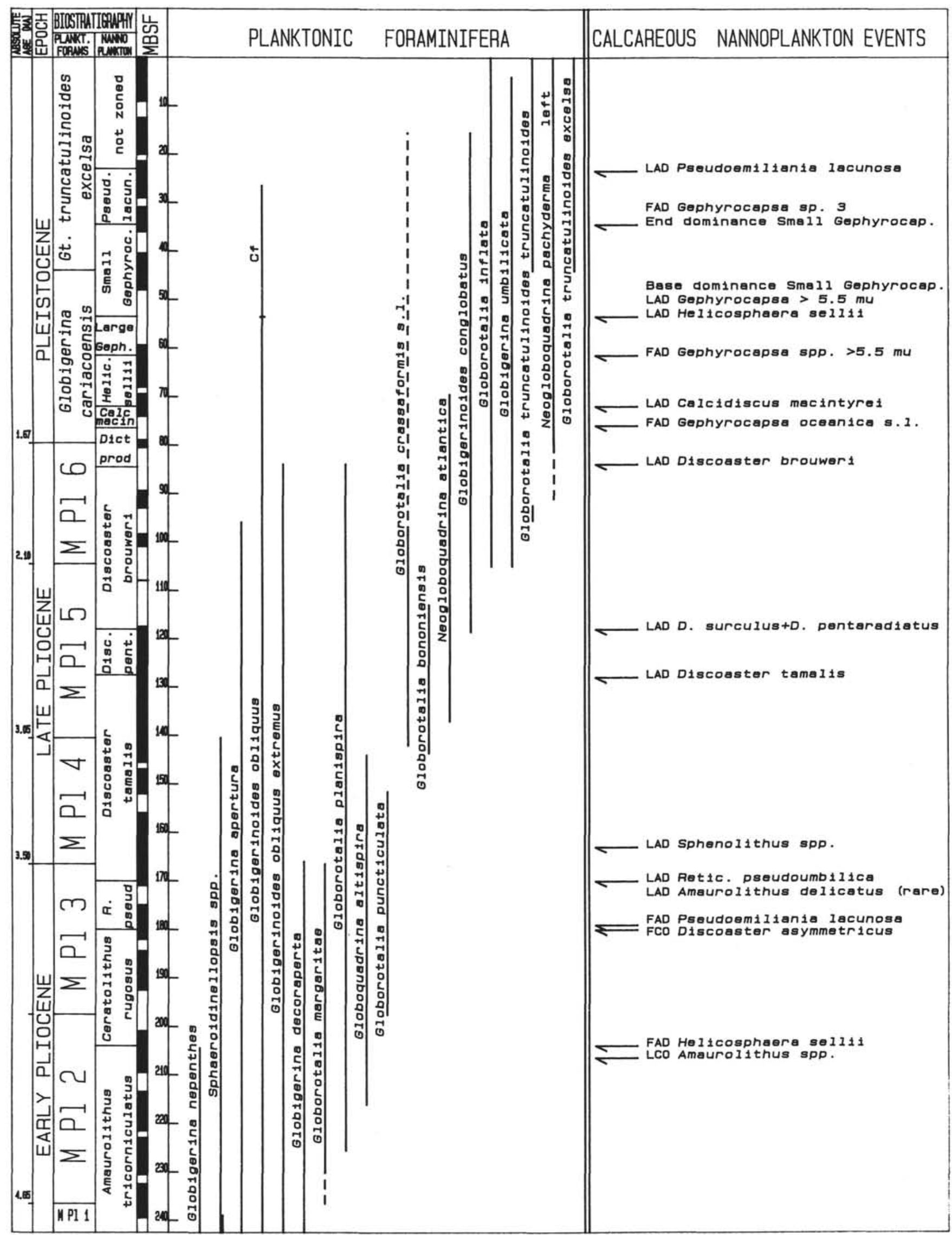

Figure 2. Planktonic foraminifer ranges and calcareous nannoplankton events in the Pliocene-Pleistocene interval of Hole 654A (from Glaçon, Rio, and Sprovieri, this volume). 


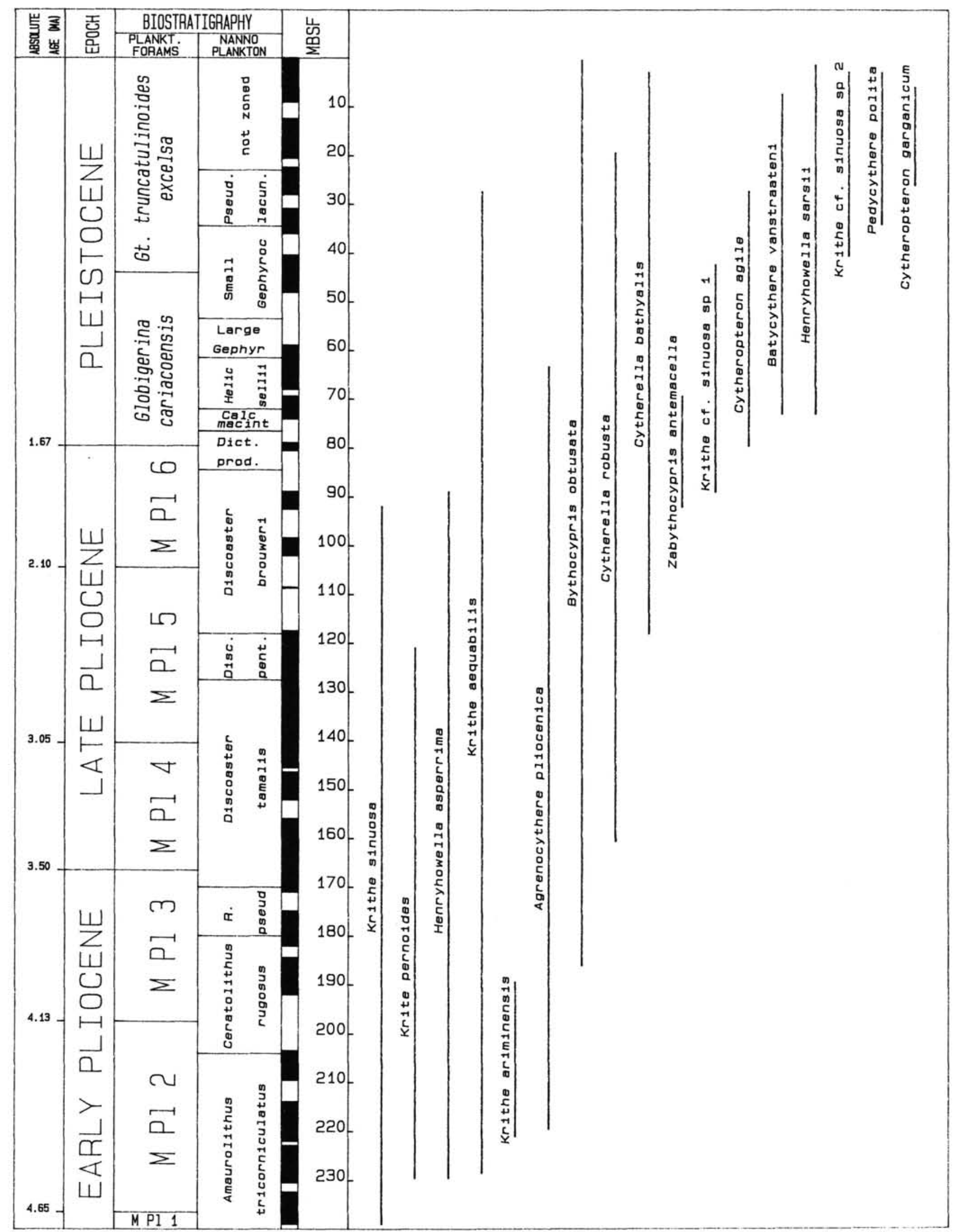

Figure 3. Stratigraphic ranges of the main taxa of ostracodes in the Pliocene-Pleistocene interval of Hole 654A. 
larly poor in species (Table 2), as in the Italian land sections (from which a greater amount of sediments per samples is obviously available). This is probably due to the delay of the ostracodes benthic fauna in the repopulation of the Mediterranean Sea at the beginning of the Pliocene, after the Messinian salinity crisis (Ruggieri, 1967a; Hsü et al., 1973).

Brief considerations about the species most significant from a biostratigraphic point of view, listed in alphabetical order, follow below.

Agrenocythere pliocenica (Seguenza)(Benson, 1972b, Textfigs. 44-50; Pl. 3, Figs. 3-4; Pl. 5, Figs. 3-4). In Hole 654A, the first occurrence of this species is in the MPI2 Zone (Sample 107$654 \mathrm{~A}-24 \mathrm{R}-5,10-12 \mathrm{~cm}$ ); the last occurrence is in the uppermost part of the Helicosphaera sellii Zone (Sample 107-654A-8R-4, $10-12 \mathrm{~cm}$ ) and slightly postdates the disappearance of the benthic foraminifers characteristic of the modern North Atlantic Deep Water (NADW, see Assemblage $C c$, discussed below and represented in Fig. 6). In some sections of the Marche and the Calabria regions (Italy) the last occurrence of $A$. pliocenica is recorded in the Large Gephyrocapsa Zone or in the lower part of the Small Gephyrocapsa Zone (Colalongo and Pasini, unpubl. data), whereas in the Le Castella section (Calabria), this event takes place a little above the lower boundary of the Globorotalia truncatulinoides excelsa Zone (upper part of the Small Gephyrocapsa Zone, Fig. 2) (compare Colalongo, 1965, with Colalongo et al., 1981).

Among the ostracodes found in Hole 654A, A. pliocenica is the only taxon considered by Benson and Sylvester-Bradley (1971) and Benson (1972a, 1973) as strictly psychrospheric. The abovementioned authors regarded as psychrospheric also Bathycythere vanstraateni (present in Hole 654A), but recently Benson (pers. comm., 1986) was very doubtful about this assumption.

Considering what we stated above and accepting - as assumed by many authors-that $A$. pliocenica is a psychrospheric ostracode, it follows that the removal of psychrospheric conditions took place in the Mediterranean Sea during or after the time interval corresponding to the Small Gephyrocapsa Zone, and not at the beginning of the Pleistocene as stated by Benson and Sylvester-Bradley (1971) and Benson (1972a, 1973, 1984).

Bythocypris obtusata (Sars) (Sars, 1923, Pl. XXX, Fig. 1). It was generally found in several Italian sections from Zone MP16 (Globorotalia inflata Zone) upward (Colalongo and Pasini, 1980, and unpubl. data). The first occurrence of this species in Hole $654 \mathrm{~A}$ was recognized in older levels; in fact it is recorded within Zone MP13 (Globorotalia margaritae-G. puncticulata Zone), more exactly within the upper part of Ceratolithus rugosus Zone, in Sample 107-654A-21R-2, 10-12 cm, 186.2 mbsf (Fig. 3 ). The frequency of $B$. obtusata increases in the Pleistocene interval of Hole $654 \mathrm{~A}$; the same feature was recognized in several cores collected from Tyrrhenian Sea by the Istituto di Geologia Marina of CNR (Bologna) and in numerous Italian land sections.

Cytherella bathyalis Bonaduce, Ciliberto, Masoli, Minichelli, and Pugliese (Bonaduce et al., 1983, Pl. 2, Fig. 5). This species was found up to now only in Recent sediments (Bonaduce et al., 1983). Its first occurrence in Hole 654A is in Sample 107-654A14R-1, 10-12 cm (117.8 mbsf), near the top of Zone MPI5 (Globigerinoides elongatus Zone).

Cytherella robusta Colalongo and Pasini (Colalongo and $\mathrm{Pa}$ sini, 1980, Pl. 10, Figs. 4-7). The first occurrence of this species is in Sample 107-654A-18R-4, 10-12 cm (160.7 mbsf), within the MP14 Zone (Sphaeroidinellopsis subdehiscens Zone). This event is recorded approximately in the same stratigraphic position also in the Italian land sections.

Krithe ariminensis Ruggieri (Ruggieri, 1967b, Text-figs. 6-9). It has been found in Italian upper Miocene (Ruggieri, 1967b; Ciampo, 1985) and lower Pliocene sediments (Colalongo, 1968).
In Hole 654A $K$. ariminensis is present-but rather rare-in MPI2 Zone and in the basal portion of MPI3 Zone.

Krithe sinuosa Ciampo (Ciampo 1985, Pl. 17, Figs. 3-5). This species, recently erected, has been found in Italian Tortonian and lower Messinian sediments (Ciampo, 1985). K. sinuosa is present throughout the Pliocene interval of Hole $654 \mathrm{~A}$; its last occurrence is a little below the Pliocene/Pleistocene boundary. In the lower Pleistocene interval of this Hole, $K$. sinuosa is replaced by a similar form, which we name provisionally $K$. cf. sinuosa sp. 1 (Pl. 1, Figs. 3-4). This provisional species is similar in size to $K$. sinuosa, but has a slightly narrower vestibulum and a smaller number of marginal pore canals.

Zabythocypris antemacella (Maddocks) (Maddocks, 1969, Text-fig. 60i-1). The $Z$. antemacella FO is recorded in Sample 107-654A-11R-3, 10-12 cm (91.8 mbsf), a little above the Globorotalia inflata FO (Figs. 2, 3). In the Italian land sections, the Z. antemacella $\mathrm{FO}$ is contemporaneous with or slightly predates the G. inflata FO (Colalongo and Pasini, 1980, and unpubl. data).

\section{Pleistocene Ostracode Fauna}

The ostracode fauna of the Pleistocene interval of Hole 654A is poor in specimens but much richer in species than the ostracode fauna of the Pliocene interval. A remarkable increase in the number of ostracode species at the beginning of the Pleistocene was observed in some Italian land sequences sedimented in bathyal environment (Colalongo and Pasini, 1980, and unpubl. data). Both in Hole 654A and in some Italian sequences there is a noticeable increase in the number of species of the genus Polycope above the base of the Large Gephyrocapsa Zone, close to the last occurrence of Agrenocythere pliocenica (Colalongo and Pasini, 1980).

Also, for the Pleistocene interval of Hole 654A, we will consider the ostracodes most significant from a biostratigraphic point of view, listing them in alphabetical order.

Bathycythere vanstraateni Sissingh (Colalongo and Pasini, 1980, Pl. 4, Figs. 7-8). The first occurrence of this species is recorded near the Pliocene/Pleistocene boundary both in Hole 654A and in some Italian land sections (Colalongo and Pasini, 1980 and unpubl. data). Therefore, the B. vanstraateni FO can be considered a useful event to approximately recognize the Pliocene/Pleistocene boundary. The $B$. vanstraateni $\mathrm{LO}$ occurs in Hole 654A within the Glacial Pleistocene, above the Pseudoemiliania lacunosa LAD (Fig. 3); this event was recognized in the same stratigraphic interval also in core $\mathrm{T} 75 / 15$, collected by the Istituto di Geologia Marina of CNR from the southeastern Tyrrhenian Sea. Consequently, the specimens of $B$. vanstraateni found by Breman (1975) and Bonaduce et al. (1983) in Holocene sediments of the Mediterranean Sea could be reworked.

Henryhowella sarsi (G. W. Müller) (Bonaduce et al., 1975, Pl. 31, Figs. 1-7). Both in Hole 654A and in some Italian Pliocene-Pleistocene sequences $H$. sarsi sensu stricto is present only in the Pleistocene sediments and seems to replace $H$. asperrima sensu stricto (Ruggieri, 1962, Pl. XXI, Figs. 16-19), which occurs only in the Pliocene sediments.

Krithe cf. sinuosa sp. 2 (Pl. 1, Figs. 1-2). Among the provisional species, $K$. cf. sinuosa sp. 2 is rather significant; its first occurrence is recorded in Sample 107-654A-6R-1, 10-12 cm (40.4 mbsf), and this species characterizes the Pleistocene sediments of Hole 654A from about the Globorotalia truncatulinoides excelsa FO upward (Figs. 2, 3). The first occurrence of this species is probably in the same stratigraphic position also in the Italian land sections (G. Ruggieri, pers. comm., 1987). K. cf. sinuosa sp. 2 (similar to $K$. tumida Brady) is characterized by a large and thick carapace, a very narrow and regular vestibulum, an anteriorly, ventrally, and posteriorly wide inner lamella and by 10-11 marginal pore canals. 
Although Cytheropteron agile Colalongo and Pasini (Colalongo and Pasini, 1980, Pl. 10, Figs. 4-7), C. garganicum Bonaduce, Ciampo, and Masoli (Bonaduce et al., 1975, Pl. 55, Figs. 7-13), and Pedicythere polita Colalongo and Pasini (Colalongo and Pasini, 1980, Pl. 24, Figs. 7-10) are present only in few samples of Hole 654A, their stratigraphic ranges in this hole seem to confirm that these species are restricted to the Quaternary.

\section{OSTRACODES Q-MODE FACTOR ANALYSIS}

Four factors were extracted by the Q-mode factor analysis from a cosine theta similarity matrix according to a varimax rotational scheme. The four entities may be regarded as distinct ostracode assemblages, their composition being epitomized in the varimax factor scores (Fig. 5) and their vertical distribution and abundance in the varimax factor loading (Fig. 4) (Davis, 1973, among others). The retained factors account for about $69 \%$ of the compositional information (variance) contained in the raw data matrix.

Significantly high communalities and improvement of variance partition after varimax rotation indicate that the selected factorial model is appropriate for our problem.

The stratigraphic distribution of the four obtained factors, plotted against depth and a detailed biostratigraphic scheme, is reported in Figure 4.

Factor 1 (Assemblage $N$ ) is dominated by Krithe aequabilis associated with Agrenocythere pliocenica and Krithe monosteracensis (Seguenza) (Pl. 1, Fig. 7, and Fig. 5). Agrenocythere is considered by many authors as a typical psychrospheric genus, which lives in waters with a temperature of $4^{\circ}-8^{\circ} \mathrm{C}$ (Benson, 1972b). The concomitant presence of the Krithinae and of the genus Agrenocythere should indicate a depth ranging from $1000-1200$ to $4500 \mathrm{~m}$ (Peypouquet, 1980). The stratigraphic distribution of Factor 1 is between 227 and 63.7 mbsf, stretching from the lower part of MPI2 Zone to the middle part of the Globigerina cariacoensis Zone (top of $H$. sellii Zone).

In Factor 2 (Assemblage $M$ ) Henryhowella asperrima and, subordinately, Agrenocythere pliocenica display high factor scores (Fig. 5). Specimens of $H$. sarsi, a taxon that several authors include in the $H$. asperrima group, were collected in recent sediments of the Mediterranean Sea from 300 to 2600 m, with a frequency maximum at about $800 \mathrm{~m}$ (Bonaduce et al., 1983). Cronin (1983) pointed out that in the Florida-Hatteras slope, species populations referred to $H$. asperrima reach high percentages at depths of $900-1070 \mathrm{~m}$. The stratigraphic distribution of Factor 2 is between 229 and $136.5 \mathrm{mbsf}$, ranging from the basal part of MPl2 Zone to the basal part of MPl5 Zone.

Factor 3 (Assemblage $O$ ) is dominated by Argilloecia acuminata G. W. Müller (Bonaduce et al., 1975, Pl. 8, Figs. 1-5, and Fig. 5). As documented by Cronin (1983), the genus can thrive in poorly oxygenated waters, attaining a remarkable abundance in the Oxygen Minimum Zone below the thermocline. The stratigraphic distribution of Factor 3 is between 75 and 19.5 mbsf, stretching from the basal part of the Globigerina cariacoensis Zone to the middle part of the Globorotalia truncatulinoides excelsa Zone.

Factor 4 (Assemblage $P$ ) is dominated by Bythocypris obtusata and Agrenocytere pliocenica (Fig. 5). The stratigraphic distribution of Factor 4 is from 175 to 118 mbsf and from 21.5 mbsf to the top of the sequence. In the lower interval, ranging from the upper part of MPl3 Zone to the middle part of MPl5 Zone, the assemblage is dominated by $A$. pliocenica. In the upper interval, belonging to the upper part of the Globorotalia truncatulinoides excelsa Zone, the assemblage is dominated by Bythocypris obtusata with a significant presence of Krithe cf.sinuosa sp. 2. In the Mediterranean area, B. obtusata has a frequency maximum around $2600 \mathrm{~m}$ (Bonaduce et al., 1983). $K$. cf. sinuosa sp. 2 shows - as we said above-a very narrow vestibulum and a large and thick carapace; according to Peypouquet $(1979,1980)$ these morphologic features are an adaptive response to well-oxygenated conditions in deep waters.

\section{BENTHIC FORAMINIFERS Q-MODE FACTOR ANALYSIS AND PALEOECOLOGICAL RESULTS}

Since the ostracode assemblages are generally poor in specimens and therefore not particularly suitable from which to draw paleoecological results, these are essentially based on the benthic foraminifer assemblages. As far as the benthic foraminifers are concerned, a quantitative raw data matrix was processed by a Q-mode factor analysis (Hasegawa, Sprovieri, and Poluzzi, this volume). The species abundances were resolved in seven varimax assemblages with distinct stratigraphic distribution, accounting for about $79 \%$ of the original variance (Fig. 6). The most salient paleoecological and paleoenvironmental results obtained by Hasegawa, Sprovieri, and Poluzzi (this volume) are reported in this chapter. The varimax factor scores on which the factors are epitomized are reported in Table 1 . The bathymetric indications are used with reference to Wright (1978).

Assemblage $A$ is defined by the third factor and is well represented in MPI1 and in the basal part of MPI2 Zones, from the base of the Pliocene to $227 \mathrm{mbsf}$. The assemblage is characterized by costate Uvigerina and by Globocassidulina spp., indicative of an upper epibathyal environment, presumably with a slightly reduced bottom oxygen content. Subassemblage $B b$ can be recognized as the positive portion of Factor 6 . It is dominated by Parrelloides robertsonianus and $P$. bradyi (more frequent), and is present only in the lower part of MPI2 Zone.

Subassemblage $B b$ is considered by Hasegawa, Sprovieri, and Poluzzi (this volume) as indicative of a lower epibathyal environment with a depth of about $800-1000 \mathrm{~m}$.

Subassemblage $B a$, typified by the predominance of Siphonina reticulata and by the subordinate presence of Parrelloides spp. and Pullenia spp., is referred to the first factor. It ranges approximately from the base of MP12 to the lower part of MP15 zone, more exactly from 229 to 127 mbsf. Living specimens of Siphonina reticulata have been recovered in the Mediterranean Sea from depths not exceeding 1000-1200 m (Parker, 1958; Bizon and Bizon, 1984). Parrelloides spp. are not living today in the Mediterranean Sea (Parker, 1958; Wright, 1978), but are present in the oceans and in the Gulf of Mexico with an upper depth limit ( $P$. bradyi) of about $450-500 \mathrm{~m}$ (Pflum, Frerich, and Sliter, 1976). These elements delineate a well-oxygenated lower epibathyal environment in a depth range of about $500-1200 \mathrm{~m}$.

Subassemblage $C c$ is represented by the second factor and is dominated by taxa with positive scores (Sigmoilopsis schlumbergeri, Miliolina, Parrelloides spp., Oridorsalis spp., and Cibicidoides pachyderma) together with a species with negative score, Siphonina reticulata. The stratigraphic extension of Subassemblage $C c$ encompasses the lower part of MPI5 Zone and the lowermost part of the Globigerina cariacoensis Zone, from 132 to 70 mbsf. Many of the above-quoted forms characterize the modern water masses of NADW (North Atlantic Deep Waters) (Lohmann, 1978), whose depth range is between 1300 and $3000 \mathrm{~m}$ (Lutze and Coulbourn, 1984). The varimax Subassemblage Cc is therefore related to an environment similar to modern NADW with a depth exceeding $1300 \mathrm{~m}$.

Subassemblage $D a$ is defined by Factor 6, based on the negative contributions of dominant Miliolina and Bolivina groups, and on the positive contributions of Parrelloides spp. It is generally not well represented in the sequence of Hole 654A. Relatively high factor loadings (near or greater than the absolute value of 0.5 ) are present essentially from the topmost part of the late Pliocene (upper part of MP16 Zone) to the lowermost part of the Pleistocene (base of Globigerina cariacoensis Zone), prac- 


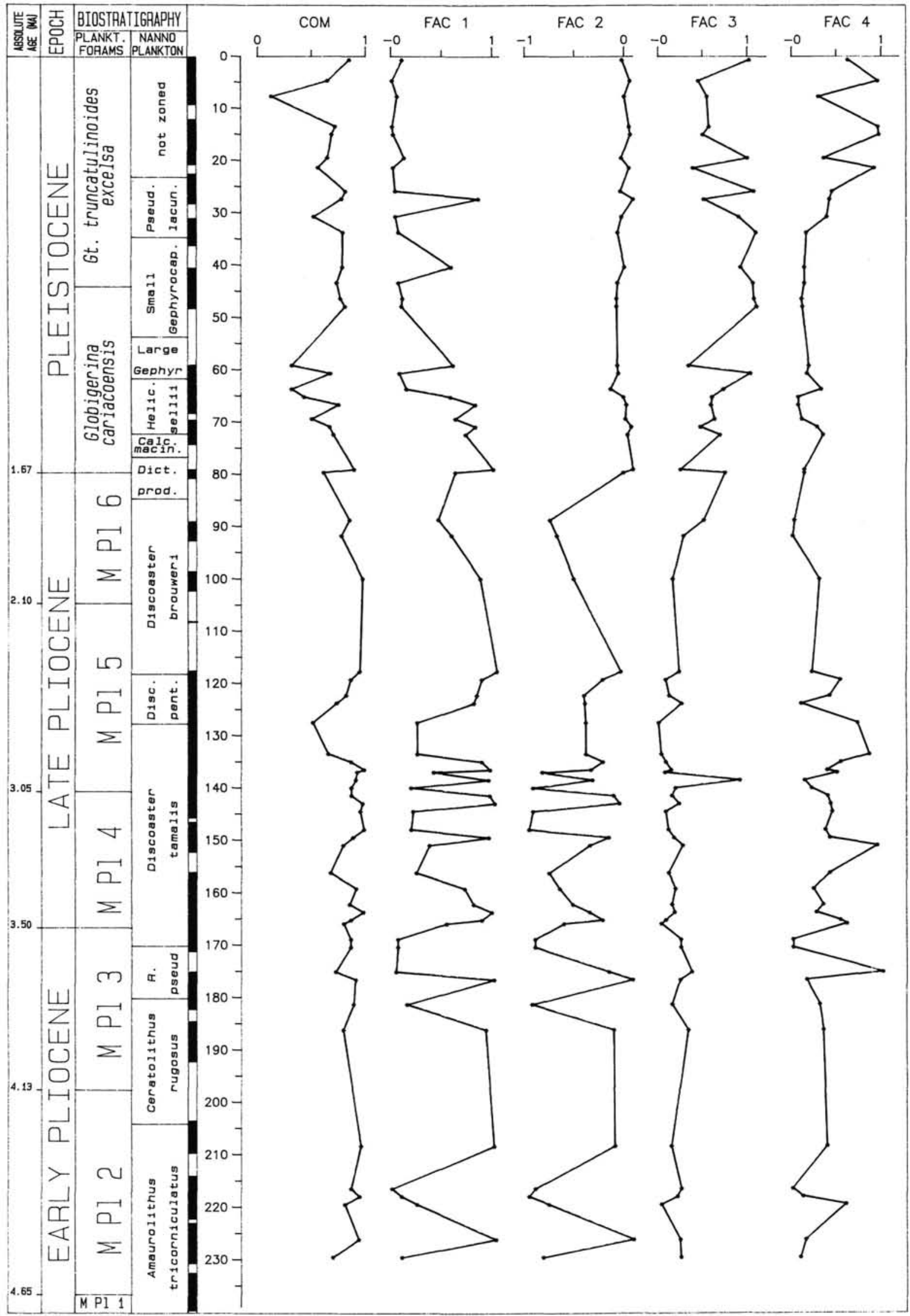

Figure 4. Communalities and varimax factor loadings of the four factors (ostracode assemblages) recognized in Hole 654A, plotted along their stratigraphic ranges. 


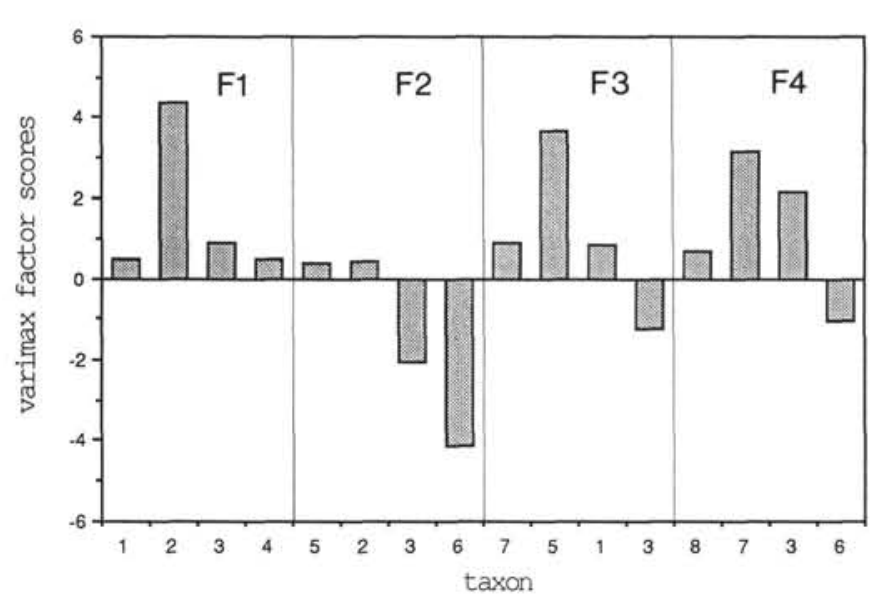

Figure 5. Scaled varimax factor scores of ostracodes on four retained factors (1-4) in the Pliocene-Pleistocene interval of Hole 654A. In abscissa, the numbers refer to dominant taxa in each assemblage: $1=$ Cytherella robusta; $2=$ Krithe aequabilis; $3=$ Agrenocythere pliocenica $; 4$ = Krithe monosteracensis; 5 = Argilloecia acuminata; 6 $=$ Henryhowella asperrima $; 7=$ Bythocypris obtusata , and $8=$ Krithe cf. sinuosa sp. 2.

tically overlapping the upper part of the interval characterized by Subassemblage $C c$. Only a single short peak is present above, at the Small Gephyrocapsa/Pseudoemiliania lacunosa boundary. Subassemblage $D a$ includes elements of the modern NADW (as Subassemblage $C c$ ), among which Cibicidoides kullembergi is present. This species, not living today in the Mediterranean basin (Parker, 1958) but abundant below $2000 \mathrm{~m}$ in the Bay of Biscay (Wright, 1978), suggests for Subassemblage $D a$ a deeper environment than for Subassemblage Cc. The depth of Subassemblage $D a$ has been evaluated by Hasegawa, Sprovieri, and Poluzzi (this volume) at about $2000 \mathrm{~m}$.

Subassemblage $D b$ is referred to Factor 4 and stretches from just above the base to the upper part of the Pleistocene (from 75 to $15 \mathrm{mbsf}$ ). The dominant taxa in Factor 4 are Articulina tubulosa and Gyroidina spp. These species have been recently found in eastern Mediterranean cores within sequences of closely spaced sapropel horizons (Mullineaux and Lohman, 1981; Parisi, 1982). These evidences suggest that the bottom water was poorly oxygenated during the time interval characterized by Subassemblage $\mathrm{Db}$.

Subassemblage $E b$ is referred to Factor 6 and is dominated by Cibicidoides pachyderma and Cassidulina carinata. It essentially marks the topmost part of the recovered sequence, from 17 mbsf upward. Subassemblage $E b$ is considered indicative of well-oxygenated bottom conditions (Hasegawa, Sprovieri, and Poluzzi, this volume).

\section{DISCUSSION}

Essentially five discrete stratigraphic intervals characterized by paleoecologically significant varimax assemblages of benthic foraminifers can be distinguished in the Pliocene-Pleistocene sequence of Hole 654A (Fig. 6): (1) the interval ranging from the base of the Pliocene to 231 mbsf; (2) the interval between 231 and 127 mbsf; (3) the interval between 127 and 70 mbsf; (4) the interval between 70 and $15 \mathrm{mbsf}$; and (5) the interval ranging from 15 mbsf to the top of the sequence.

The basal interval, belonging to MPI1 and to the lowermost part of MPI2 Zones, is characterized by the foraminifer Assemblage $A$. It testifies to an upper epibathyal environment, presumably with slightly underoxygenated bottom conditions. Ostracodes are extremely rare in this stratigraphic interval, as generally recognized also in Italian land sections.
The interval between 231 and $127 \mathrm{mbsf}$, from the lower part of MPl2 to the middle part of MP15 Zones, is characterized by the foraminifer varimax Subassemblages $B a$ and $B b$. Subassemblage $B b$-present only in the basal part of the interval-indicates a lower epibathyal environment and, more exactly, a depth of about $800-1000 \mathrm{~m}$. Also Subassemblage $\mathrm{Ba}$-present throughout the interval-is indicative of a lower epibathyal environment, with a depth of 500-1200 m, and of well-oxygenated bottom conditions. In the same stratigraphic interval, ostracode Assemblage $M$ and $N$ co-occur; in the upper part of this interval also Assemblage $P$ (lower portion, Fig. 6 ) is present. Assemblage $M$ is dominated by taxa which display maximum frequency between 800 and $1100 \mathrm{~m}$ in depth. Assemblage $N$ is dominated by taxa indicative of depth from 1000-1200 to 4500 $\mathrm{m}$, and of cold waters (as suggested also by the lower portion of Assemblage $P$ ). The highest loadings of Assemblages $M$ and $N$ repeatedly alternate along the interval. This indicates in our opinion that, during the lapse of time corresponding to this interval, the seafloor depth at Site 654 was close to the bathymetric threshold (about 1000-1100 m) which seems to separate the two different ostracode assemblages. Therefore the paleobathymetric indications provided for this interval by the benthic foraminifer assemblages are in good agreement with the ones suggested by the ostracode assemblages. The ostracode assemblages may even allow a more precise definition of the bathymetric conditions.

The interval between 127 and 70 mbsf is dominated by benthic foraminifer Subassemblage $C c$, with overlapping occurrence of Subassemblage $D a$ in its upper part. Both these subassemblages include modern NADW faunistic elements. In the Pliocene part of the interval, Subassemblage $C c$ is indicative of depth greater than about $1300 \mathrm{~m}$; in the Pleistocene part of the interval, the co-occurrence of Subassemblage $C c$ and Subassemblage $D a$ is indicative of depth of about $2000 \mathrm{~m}$, close to the present depth of Site 654. Approximately in the same stratigraphic interval only, ostracode varimax Assemblage $N$, indicative of depth ranging from $1000-1200$ to $4500 \mathrm{~m}$, is present. Therefore, again, the paleoenvironmental conditions indicated by the benthic foraminifer assemblages are suitable for the ostracode assemblage recognized in the same stratigraphic interval.

In the interval between 70 and $15 \mathrm{mbsf}$, essentially benthic foraminifer Subassemblage $D b$ and ostracode Assemblage $O$ are present. The paleoecological meanings of these varimax assemblages are in good agreement because both of them require poorly oxygenated bottom conditions. In the upper part of the same interval also Subassemblage $D a$, indicative of a depth of about $2000 \mathrm{~m}$, is represented.

In the uppermost part of the Pleistocene sequence of Hole $654 \mathrm{~A}$ benthic foraminifer Subassemblage $E b$ and ostracode Assemblage $P$ (upper portion) are present. Both assemblages are indicative of well-oxygenated bottom conditions and are therefore again in good agreement.

\section{CONCLUSIONS}

The stratigraphic ranges of the ostracodes of Hole 654A have been related to the calcareous plankton biostratigraphy of the same sequence. Such an approach has permitted us to outline or, in some cases, to confirm the stratigraphic significance of several Mediterranean deep-water Pliocene-Pleistocene ostracodes scantily studied up to now, and to ascertain that the psychrospheric conditions lasted in the Mediterranean Sea at least till the time interval corresponding to the Small Gephyrocapsa Zone.

The relative frequencies of benthic foraminifers and ostracodes recovered in Hole 654A were processed by the CABFAC program and resulted in seven varimax assemblages of foraminifers and four varimax assemblages of ostracodes.

Despite the small number of specimens on which the ostracode analysis is based, the paleoenvironmental indications sug- 
Table 1. Scaled varimax factor scores of benthic foraminifers on six retained factors in the Pliocene-Pleistocene interval of Hole $654 \mathrm{~A}$. The six factors account for about $79 \%$ of the original variance (from Hasegawa, Sprovieri, and Poluzzi, this volume).

\begin{tabular}{|c|c|c|c|c|c|c|}
\hline & FACTOA 1 & FACTOA 2 & FACTOA 3 & FACTOA 4 & FACTOA 5 & FACTOA 6 \\
\hline Anomalinoides helicinus & .1798 & .0841 & .2324 & -.0167 & -.0364 & .4796 \\
\hline Articulina tubulosa & .0766 & -1.0800 & -.6587 & 4.5670 & 1.1237 & -.0573 \\
\hline Astrononion spp. & 1.2226 & -.1215 & .7572 & -.3007 & -.3359 & -.7411 \\
\hline Bigenerina nodosaria & .8723 & 1.2916 & -.0309 & -.2966 & -.5147 & .8173 \\
\hline Bolivina group & .3218 & 1.6404 & .4474 & .1904 & .6230 & -3.2283 \\
\hline Smooth Bulimina & .0431 & .2233 & .0372 & -.0462 & -.1073 & .0453 \\
\hline Costate Bulimina & .0288 & -.1562 & .3334 & .5908 & 1.0341 & .1321 \\
\hline Cassidulina carinata & .0163 & -.2990 & -.0328 & .2940 & 3.9317 & -.1600 \\
\hline Chilostome1la spp. & .0038 & -.0231 & -.0028 & .0601 & .0757 & .0417 \\
\hline Cibicides spp. & .0569 & .1714 & .1796 & -.0741 & -.0104 & -.3754 \\
\hline Cibicides wuellestorfi & -.0671 & .4147 & .0255 & -.1393 & -.0756 & -.0443 \\
\hline Cibicidoides spp. & .6567 & .1750 & .0667 & -.2004 & -.4373 & -.9462 \\
\hline Cibicidoides (?) italicus & $1 \cdot 1296$ & -.3562 & -.2152 & .0580 & -.1075 & .2501 \\
\hline Cibicidoides kullenbergi & -.0033 & -.0710 & -.1060 & .5869 & .8368 & .0731 \\
\hline Libicidoides pachyderma & -.2881 & 1.4498 & 1068 & -.8028 & 4.4012 & .4782 \\
\hline Eggere11a bradyi & .2976 & .6885 & -.0399 & .0561 & .0081 & .2910 \\
\hline Globobulimina group & .0169 & -.0799 & .0456 & .1335 & .5386 & .1938 \\
\hline Globocassidulina group & -.1312 & .7220 & 2.2881 & .9819 & -.7052 & .0692 \\
\hline Gyroidina group & .5275 & 1.0142 & 1.3803 & 3.4574 & -.7787 & 1.4179 \\
\hline Hanzawaia rodhiensis & .7835 & 1.4433 & .1204 & .1681 & -.9068 & -1.4328 \\
\hline Hoeglundina elegans & -.0028 & .0079 & -.0021 & .0075 & .0060 & -.0224 \\
\hline Hyalinea baltica & .0011 & -.1018 & .0008 & .4692 & .0766 & .0729 \\
\hline Karreriella spp. & .7704 & .8882 & .2617 & .1559 & .1604 & .7198 \\
\hline Laticarinina pauperata & .0034 & .0098 & -.0062 & -.0025 & -.0098 & -.0151 \\
\hline Martinottiella spp. & .1557 & -.1028 & .1860 & .0797 & -.0425 & -.1272 \\
\hline Miliolina & .3352 & 2.6170 & -.5525 & .4712 & .2469 & -3.6083 \\
\hline Nodosariidae & .5348 & -.0350 & 1.1251 & .0746 & -.0729 & .3337 \\
\hline Nonionella spp. & .1821 & .1119 & .7137 & -.1187 & -.1462 & -.0435 \\
\hline Oridorsalis spp. & 1.2333 & 1.9719 & 1.3114 & -.4191 & 1.0030 & 1.7494 \\
\hline Parrelloides spp. & 1.5518 & 2.1048 & -.5889 & -.4906 & -.5563 & 2.0340 \\
\hline Planulina ariminensis & .2157 & .3435 & -.0483 & -.0991 & -.1660 & -.0656 \\
\hline Pleurostome 1 la alternans & .4108 & -.0437 & .6769 & .1007 & -.1007 & -1.0273 \\
\hline Pullenia spp. & 1.8837 & 1.5958 & -.4270 & .2991 & .4388 & 1.9651 \\
\hline Pyrgo spp. & .0602 & .1849 & -.2090 & .8228 & 1.4591 & -.3075 \\
\hline Pseudoparrella group & -.3473 & 1.4562 & 1.0338 & -.5981 & -.5055 & -.0006 \\
\hline Rutherfordoides tenuis & .0096 & -.0517 & .0134 & .0608 & .2921 & .1059 \\
\hline Sigmoilinita tenuis & .0768 & .0436 & .6240 & 2.4605 & -.8140 & -.5945 \\
\hline Sigmoilopsis schlumbergeri & .1201 & 2.8013 & -.6409 & .2794 & -.7014 & -.2474 \\
\hline Siphonina reticulata & 5.7066 & -2.2793 & -.0756 & -.4672 & .3582 & $-1 \cdot 1174$ \\
\hline Sphaeroidina bulloides & .2095 & -.2770 & 2.0303 & .1875 & -.1591 & 1.0584 \\
\hline Stainforthia complanata & .0301 & .2115 & -.0273 & 1.0009 & .1399 & -.1340 \\
\hline Stilostomel1a spp. & .0014 & .0071 & .3282 & .8790 & -.0086 & -.1648 \\
\hline Trifarina spp. & .0049 & -.0421 & .0073 & .4586 & .2286 & -.0275 \\
\hline Spinose Uvigerina & .0106 & .1638 & -.0462 & .0012 & -.0748 & -.0987 \\
\hline Costate Uvigerina & -.3546 & -.6821 & 5.2110 & -.8243 & .5977 & -.8000 \\
\hline Valvulineria spp. & .1507 & .1484 & .3455 & .1164 & -.1952 & .0227 \\
\hline Textulariina & .3769 & .1569 & -.2024 & .9857 & .1079 & -.4223 \\
\hline
\end{tabular}

gested by the ostracode varimax assemblages are not in conflict with the better founded paleoenvironmental indications offered by the corresponding benthic foraminifer varimax assemblages.

The varimax assemblage present in the lowermost interval of the sequence, from the base of the Pliocene to the lowermost part of MPI2 Zone, documents an upper epibathyal environment and slightly under-oxygenated bottom conditions.

The interval stretching from the lowermost part of MP12 Zone to the middle part of MP15 Zone is characterized by varimax assemblages indicative of a lower epibathyal environment and of well-oxygenated bottom conditions.

From the lower part of MP15 Zone upward, new assemblages testify to further deepenings of the bottom, reaching a value of about $2000 \mathrm{~m}$ at the Pliocene/Pleistocene boundary. An evidence of this evolving situation is represented by the entrance of frequent modern NADW members in the foraminifer subassemblages.

From the lower part of the early Pleistocene to the late Pleistocene (a little above the Pseudoemiliania lacunosa extinction level) the bottom environment was poorly oxygenated, as documented by the two taxonomically distinct varimax assemblages occurring in this interval. The sapropel and the sapropelic layers detected in the same stratigraphic interval of Hole 654A substantiate this interpretation.

The two varimax assemblages present in the topmost part of the sequence document well-oxygenated bottom conditions.

In conclusion, this study suggests a close relationship between the benthic foraminifers and the ostracodes as paleoenvironmental indicators, although they pertain to very different zoological taxa. 
Table 2. Quantitative range chart of the ostracodes in the Pliocene-Pleistocene interval of Hole 654A.

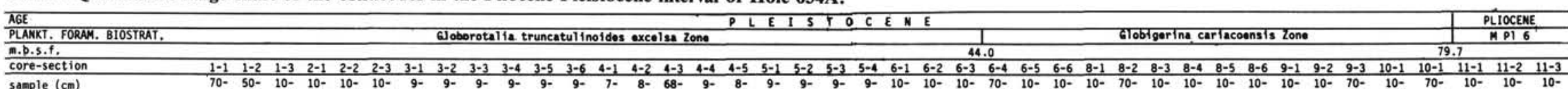

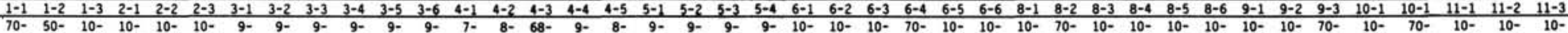

Agrenocythere pliocenica Argilloecia acuminats

Argilloecía conoidea

Argilloecia sp.

Bathycythere vanstraateni

Buntonia multicostata

"Bythoceratina" foveolate

Bythocypris obtusata

Bythocypris cf. reflexe

Bythocypris aff. tonera

Cytherolla bathyal is

Cytherella robusta

Cytheroptoron agile.

cytheropteron garganicum

Cytheropteron ef. lancet

cytheropteron cf. rotundatum

cytheropteron of trapozitu

cythoropteron venustum

Henryhowella asperrima

Henryhowella șars:

Krithe aequabilits

Krithe ariminensis

krithe compresse

Krithe monosteraconsis

Krithe pernotdes

krithe aff. praetexta

Krithe sinuose

krithe cf. sinuosa sp. 1

Krithe cf. sinuosa sp. 2

Patjenborche 1la m. cymbula

parakrithe dimorpha

Pedicythere polita

"Pedicythere" tessellate

polycope frequens

Polycope orbulinaeformis

polycope cf. parareticulata

polycope aff. punctata

polycope ef. vasfiensis

Pseudocythere caudata

Tuberculocythere tetrapteron

Zabythocypris antemace lla

Bairdia spp. (Instars)

Cytherella spp. (instars)

Cytheropteron spp. (instars)

krithe spp. (instars)

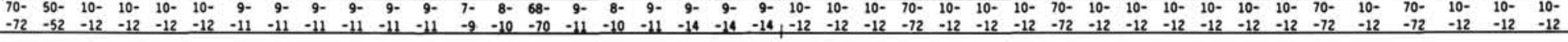

Polycope spp. (instars) 
Table 2 (continued).

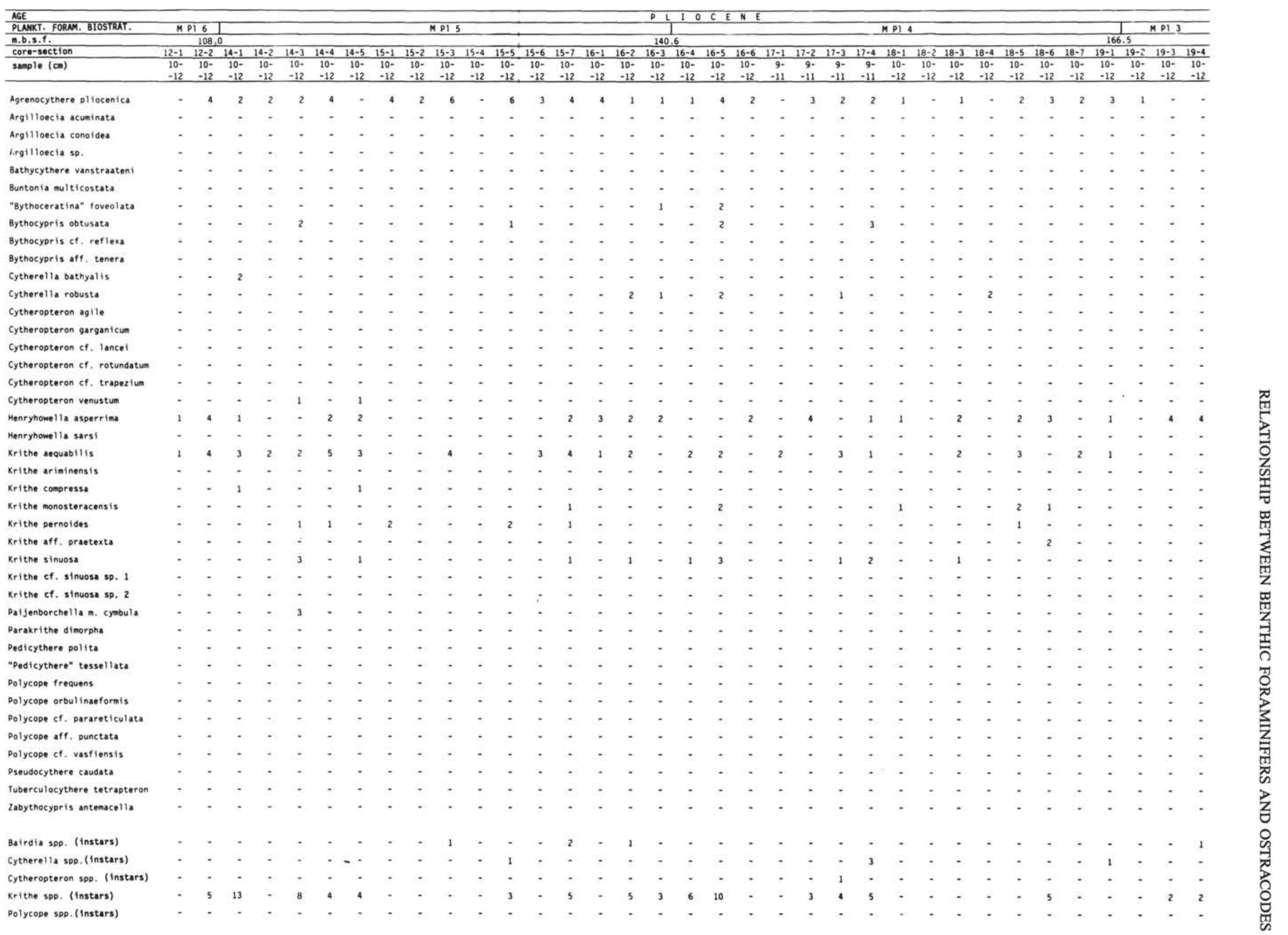


Table 2 (continued).

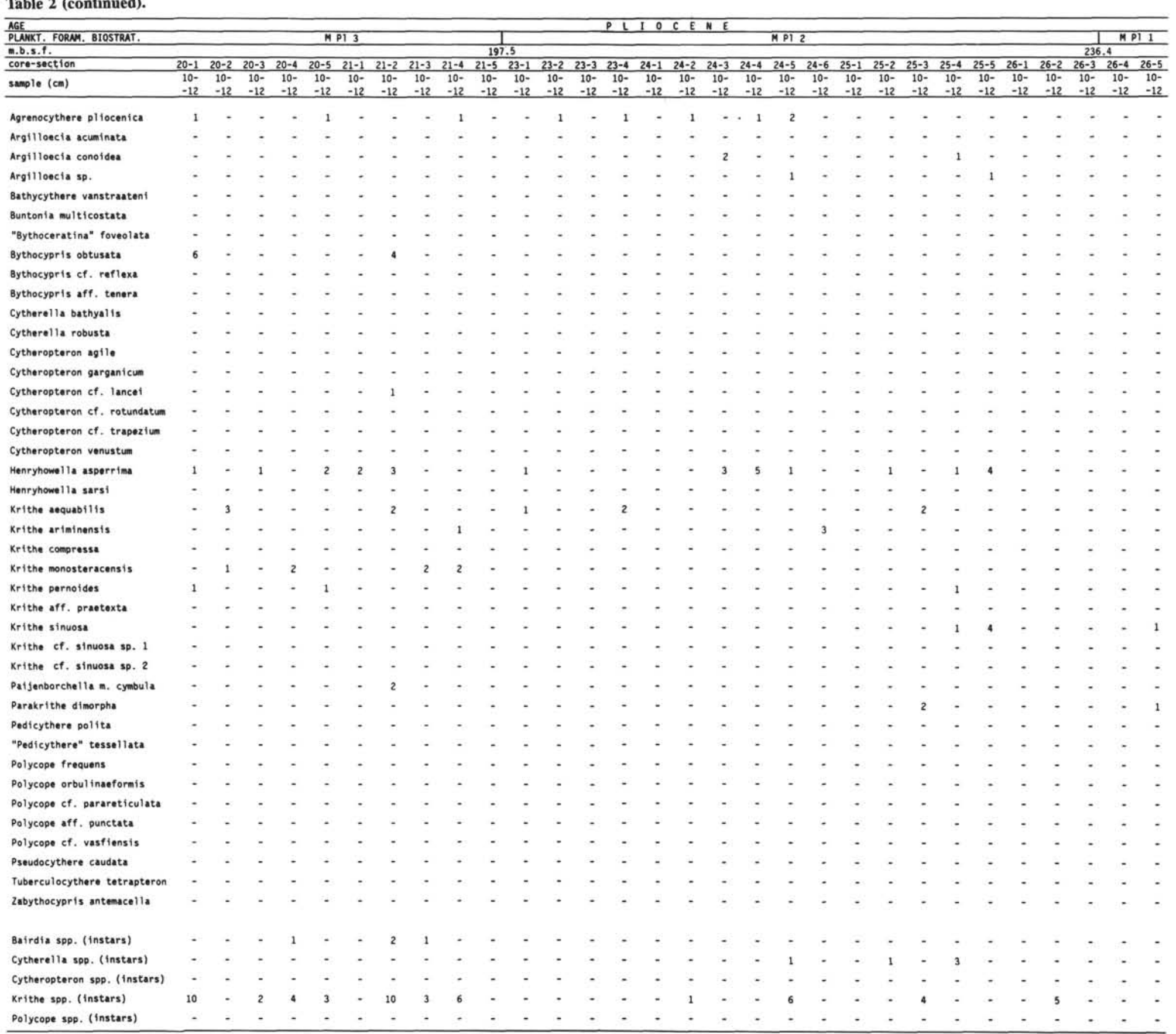




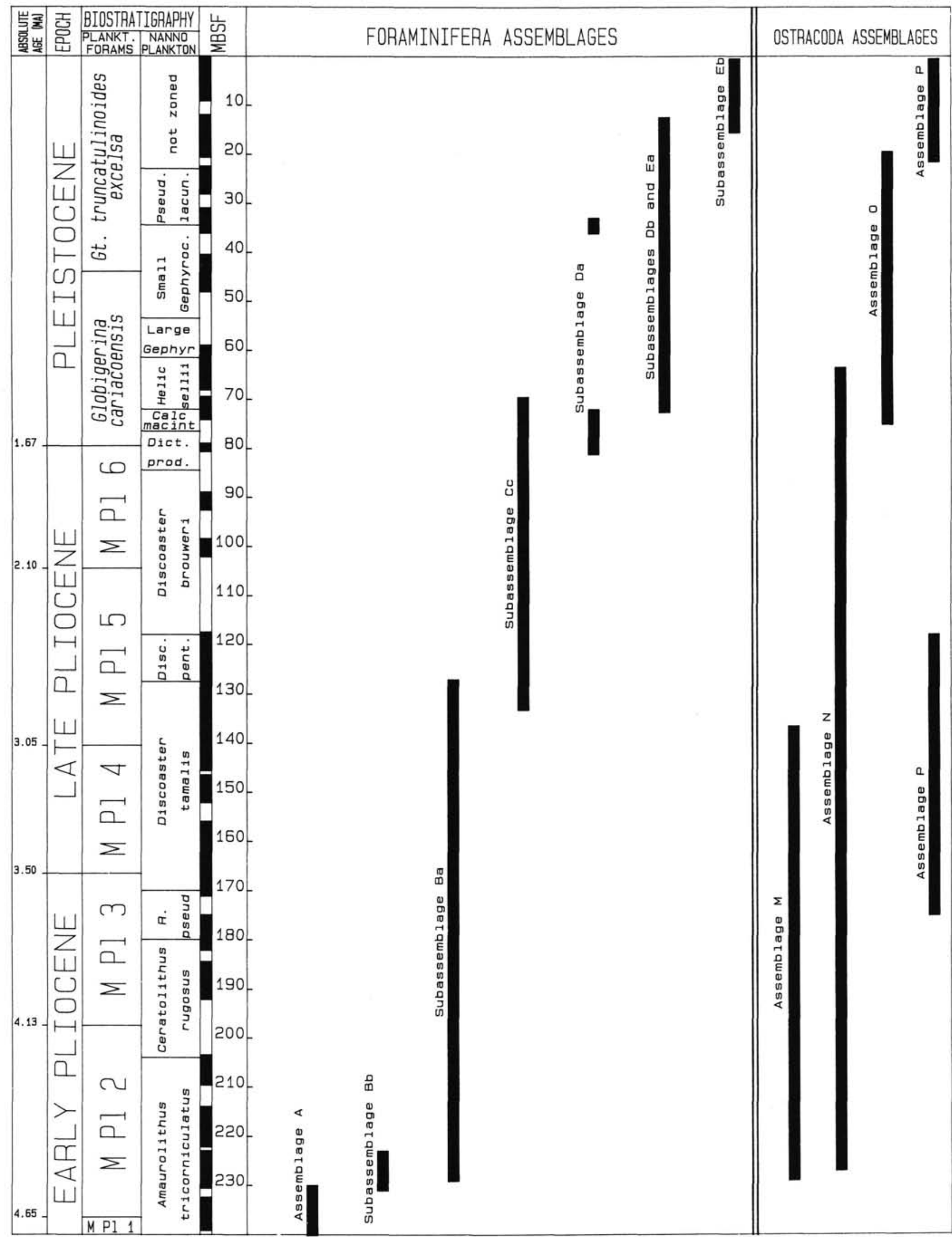

Figure 6. Stratigraphic ranges of the benthic foraminifer and ostracode varimax assemblages in the Pliocene-Pleistocene interval of Hole 654A. 


\section{ACKNOWLEDGMENTS}

The authors thank R. H. Benson, K. A. Kastens, and G. Ruggieri for the critical reviews of the manuscript.

This study was supported by the Italian National Research Council (CNR) grants CT86.00649.05 and CT87.00887.05, and by the Italian Ministry of Education (grants MPI 60\%, M. L. Colalongo, and MPI $40 \%$, S. Sartoni).

\section{REFERENCES}

Aguirre, E., and Pasini G., 1985. The Pliocene-Pleistocene boundary. Episodes, 8:116-120.

Benson, R. H., 1972a. Ostracodes as indicators of threshold depth in the Mediterranean during the Pliocene. In Stanley, D. J., (Ed.). The Mediterranean Sea: A Natural Sedimentation Laboratory: Stroudsburg, PA (Dowden, Hutchinson and Ross).

1972b. The Bradleya problem, with descriptions of two new psychrospheric Ostracode genera, Agrenocythere and Poseidonamicus (Ostracoda: Crustacea). Smithsonian Contrib. Paleobiol., 12:1138.

1973. Psychrospheric and continental ostracoda from ancient sediments in the floor of the Mediterranean. In Ryan, W.B.F., Hsü, K. J., et al., Init. Repts. DSDP, 13: Washington (U.S. Govt. Printing Office), 1002-1008.

1978. The paleoecology of the ostracodes of DSDP Leg 42A. In Hsü, K. J., Montadert, L., et al., Init. Repts. DSDP, 42A: Washington (U.S. Govt. Printing Office), 777-786.

1984. Estimating greater paleodepth with Ostracodes, especially in past thermospheric oceans. Palaeogr., Palaeoecol., Palaeoeclimatol., 48:107-141.

Benson, R. H., and Sylvester-Bradley, P. C., 1971. Deep-sea ostracodes and the transformation of ocean to sea in the Tethys. Bull. Centre Rech. Pau-SNPA, 5:63-92.

Bizon, G., and Bizon, J. J., 1984. Les foraminiféres des sédiments profonds. In Bizon, J. J., and Burollet, P. F. (Eds.), Ecologie des microorganismes en Méditerranée occidentale (ECOMED): Paris (Assoc. Fr. Tech. Petrol.), 104-139.

Bonaduce, G., Ciampo, G., and Masoli, M., 1975. Distribution of Ostracoda in the Adriatic Sea. Pubbl. Stat. Zool. Napoli, 40:1-154.

Bonaduce, G., Ciliberto, B., Masoli, M., Minichelli, G., and Pugliese, N., 1983. The deep-water benthic ostracodes of the Mediterranean. In Maddocks, R. F.(Ed.), Application of Ostracoda. Proc. 8th Symp. Ostr., Houston:459-471.

Breman, E., 1975. The distribution of ostracodes in the bottom sediments of the Adriatic Sea. (Ph. D. Dissert.). Univ. Amsterdam.

Ciampo, C., 1985. Ostracodi del limite Tortoniano/Messiniano in alcune sezioni italiane. Boll. Soc. Paleontol. It., 24:29-110.

Colalongo, M. L., 1965. Gli Ostracodi della serie di Le Castella (Calabria). G. Geol., 33:83-123.

, 1968. Cenozone a Foraminiferi Ostracodi nel Pliocene e basso Pleistocene della serie del Santerno nell'Appennino romagnolo. $G$. Geol., 35:29-61.

Colalongo, M. L., and Pasini, G., 1980. La ostracofauna plio-pleistocenica della sezione Vrica in Calabria (con considerazioni sul limite Neogene/Quaternario). Boll. Soc. Paleontol. It., 19:44-126.

Colalongo, M. L., Pasini, G., and Sartoni, S., 1981. Remarks on the neogene/Quaternary boundary and the Vrica Section (Calabria, Italy). Boll. Soc. Paleontol. It., 20:99-120.

Corliss, B. U., 1985. Microhabitats of benthic foraminifera within deepsea sediments. Nature, 314:435-438.
Cronin, T. M., 1983. Bathyal Ostracodes from the Florida-Hatteras slope, the straits of Florida, and the Blacke Plateau. Mar. Micropaleontol., 8:89-119.

Davis, J. C., 1973. Statistics and Data Analysis in Geology. New York (Wiley). Hsü, K. J., Cita, M. B., and Ryan, W.B.F., 1973. The origin of Mediterranean evaporites. In Ryan, W.B.F., Hsü, K. J., et al., Init. Repts. DSDP, 13: Washington (U.S. Govt. Printing Office), 1203-1231.

Imbrie, J., and Kipp, N. G., 1971. A new micropaleontological method for quantitative paleoclimatology: application to a late Pleistocene Caribbean core. In Turekian, K. K. (Ed.), The late Cenozoic Glacial Ages: New Haven (Yale Univ. Press), 71-181.

Lohmann, G. P., 1978. Abyssal benthonic Foraminifera as hydrographic indicators in the western south Atlantic Ocean. J. Foram. Res., 8:34.

Lutze, G. E, and Coulbourn, W. T., 1984. Recent benthic Foraminifera from the continental margin of North West Africa: community structure and distribution. Mar. Micropaleontol., 8:361-401.

Maddocks, R. F., 1969. Revision of Recent Bairdiidae (Ostracoda). U.S. Nat. Mus. Bull., 295:1-126.

Mullineaux, L. S., and Lohmann, G. P., 1981. Late Quaternary stagnation and recirculation of the eastern Mediterranean. J. Foram. Res., 11:20-39.

Parisi, E., 1983. Distribuzione dei Foraminiferi bentonici in una carota della dorsale mediterranea (Pleistocene medio e superiore). Riv. It. Paleontol. e Stratigr., 8:641-677.

Parker, F. L., 1958. Eastern Mediterranean Foraminifera. Rept. Swed. Deep-Sea Exped., 1947-48, 8:217-283.

Pasini, G., and Colalongo, M. L., in press. Sedimentology, biostratigraphy, magnetostratigraphy, biochronology, and radiometric datings of the Vrica section in Calabria (Italy). In Van Couvering, J. (Ed.), The Neogene-Quaternary boundary. Final rept. IGCP Proj. no. 41.

Peypouquet, J. P., 1979. Ostracodes et paléoenvironnements. Méthodologie et application aux domaines profonds du Cénozoique. Bull. B.R.G.M., 1:3-79.

1980. Les rélations ostracodes-profondeur. Principles applicables pendant le Cénozoique. Bull. Inst. Géol, Bassin d'Aquitaine, 28:13-28.

Pflum, C. E., Frerich, W. E., and Sliter, W. V., 1976. Gulf of Mexico deep-water Foraminifers. Foram. Res. Spec. Publ., 14:1-125.

Ruggieri, G., 1962. Gli Ostracodi marini del Tortoniano di Enna, nella Sicilia Centrale. Palaeontol. It., 56:1-68.

1967a. The Miocene and later evolution of the Mediterranean Sea. In Adams, C. G., and Ager, D. V. (Eds.), Aspects of Tethyan Biogeography. London (Systematics Assoc.), 7:283-290. 1967b. Due ostracofaune del Miocene alloctono della Val Marecchia. Riv. It. Paleontol. Stratigr., 73:351-384.

Sars, G. O., 1923. Ostracoda. In An Account of the Crustacea of Norway, 9(3-4):33-72.

Sen Gupta, B. K., Temples, T. J., and Dallmeyer, G.M.D., 1982. Late Quaternary benthic Foraminifera of the Grenada Basin: Stratigraphy and paleoceanography. Mar. Micropaleontol., 7:297-309.

Weston, K. F., and Murray, J. W., 1984. Benthic Foraminifera as deepsea water-mass indicators. In Oertly, H. J. (Ed.), Benthos '83, Second Int. Symp. Benthic Foraminifera: Pau, 605-610.

Wright, R., 1978. Neogene paleobathymetry of the Mediterranean based on benthic Foraminifers from DSDP Leg. 42A. In Hsü, K. J., Montadert, L., et al., Init. Repts. DSDP, 42A: Washington (U.S. Govt. Printing Office), 837-846.

Date of initial receipt: 2 December 1988

Date of acceptance: 10 January 1989

Ms 107B-151 


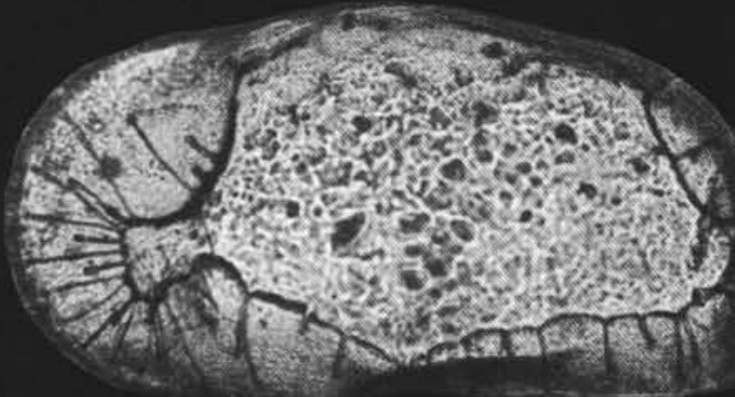

1

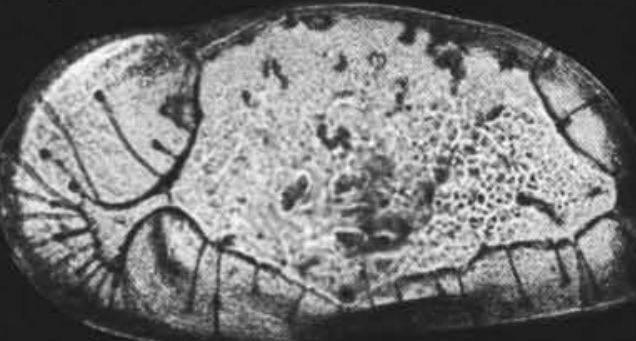

3

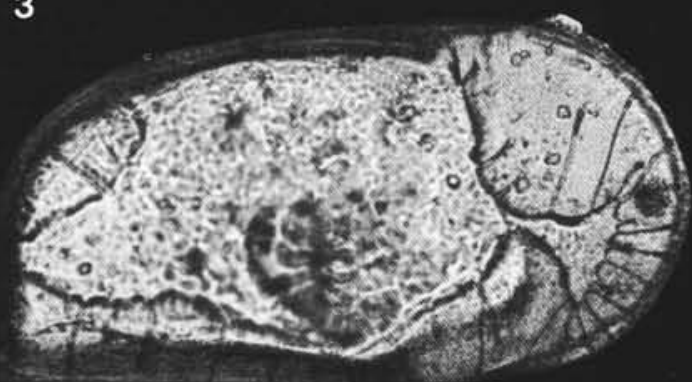

4

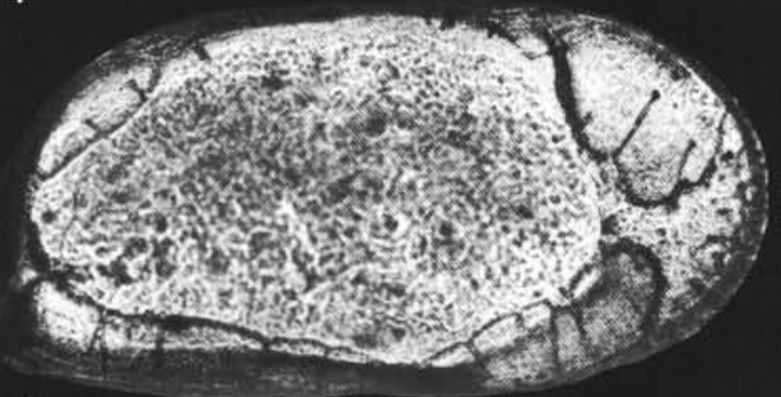

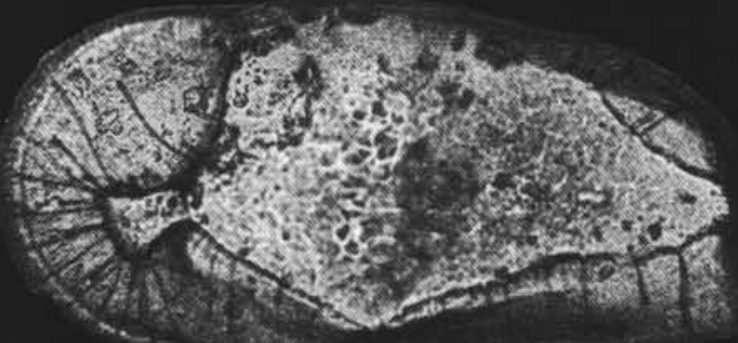

2

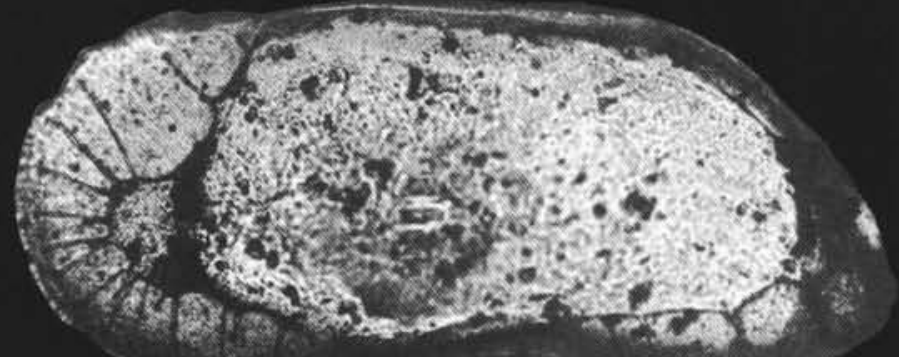

5

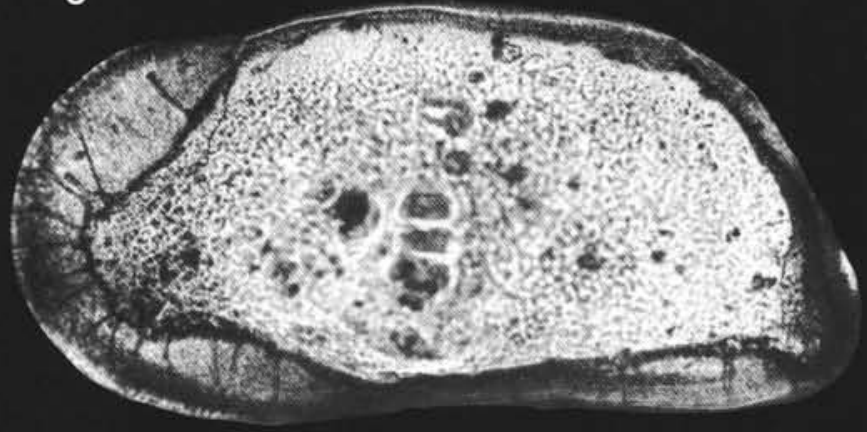

6

$0.5 \mathrm{~mm}$

7

Plate 1. Pliocene-Pleistocene ostracodes of Hole 654A (lateral exterior views, transparency). 1-2. Krithe cf. sinuosa sp. 2; left valves; female and male, respectively; Sample 107-654A-4R-1, 69-71 cm. 3-4. Krithe cf. sinuosa sp. 1; left valve (female) and right valve (male), respectively; Sample 107-654A-9R-2, 10-12 cm. 5-6. Krithe aequabilis Ciampo; left valves; male and female, respectively; Sample 107-654A-14R-1, 10-12 cm. 7. Krithe monosteracensis (Seguenza); right valve of a male; Sample 107-654A-15R-7, 10-12 cm. 